\title{
Distribution and ecology of calanoid species in relation to morphometric and chemical characteristics of lakes and ponds of the Northern Apennines (Italy)
}

\author{
Silvia TAVERNINI, Elena FRATTA, Franco SARTORE and Giampaolo ROSSETTI* \\ Department of Environmental Sciences, University of Parma, Parco Area delle Scienze 33A, 43100 Parma, Italy \\ *e-mail corresponding author: giampaolo.rossetti@unipr.it
}

\begin{abstract}
In 1999 a limnological campaign was carried out in 89 water bodies located in 8 valleys of the Northern Apennines (provinces of Genua, Piacenza, Parma and Reggio Emilia) at an altitude between 877 and $1772 \mathrm{~m}$ a.s.l. This survey took into account permanent lakes, but also temporary and ephemeral water bodies which had been scarcely considered in hydrobiological studies previously carried out in this area. Most of the biotopes were visited seasonally during the ice-free period (May - November). The aim of this research was to define the relationships between morphometric features, lithology, hydroperiod and chemical characteristics of the biotopes and the distribution of the three species of calanoid copepods reported in the Northern Apennines, i.e. Mixodiaptomus kupelwieseri, M. tatricus and Eudiaptomus intermedius. The two most common species, M. kupelwieseri and E. intermedius, show an overlap in their altitudinal distribution. However, the former species widely occurs in very shallow, temporary or ephemeral water bodies and the latter clearly prefers permanent, relatively deep waters. Also the water inonic concentration influences the distribution of these two diaptomids, while concentrations of dissolved inorganic nutrients seem to have a negligible effect. Mixodiaptomus tatricus was found only in two shallow ponds beyond $1700 \mathrm{~m}$ a.s.l. Co-occurrence of $\mathrm{E}$. intermedius and M. kupelwieseri has been observed only in a pond, but the two species are not found at the same time. The proportion of subitaneous and resting eggs laid in different seasons was analysed in populations of $\mathrm{E}$. intermedius. The voltinism of this species varies according to the duration of the filling period and the productivity of the water bodies. The persistence of diaptomids in the study area has been evaluated through the comparison with distributional data available from the 1950s for most of the permanent lakes and some temporary habitats. Populations appear to be stable over time also in scarcely predictable environments as temporary pools, although in some cases calanoids have disappeared from biotopes severely affected by anthropogenic impacts.
\end{abstract}

Key-words: Northern Apennines, high-altitude water bodies, Calanoida, distribution, ecology, reproductive patterns

\section{INTRODUCTION}

Studies on ecology and distribution of calanoid copepods have received growing attention in the last years, due to their central role in the lacustrine food webs and the relationships between species occurrence and environmental characteristics of the aquatic ecosystems (Jamieson 1998; Liss et al. 1998; Walsh \& Tyler 1998; Torke 2001).

We investigated the distribution of three diaptomid species, Mixodiaptomus kupelwieseri, M. tatricus and Eudiaptomus intermedius, in high elevation biotopes in the central part of the Northern Apennines. This district is particularly rich in lakes and pools which are naturally fishless and are characterised by small surface areas and limited depths. There is a wide variability in watershed lithology, which clearly influences the water chemistry and the susceptibility of lakes to acidification (Viaroli et al. 1992). The higher and less accessible environments are still in pristine conditions, although the introduction of trout, seldom illicit, is documented for many lakes. Some lower lakes, especially those close to mountain resorts and frequented by tourists, show symptoms of accelerated eutrophication (Viaroli et al. 1994).
Pioneering surveys by Brian $(1927,1932)$ gave a preliminary description of the copepod fauna of Northern Apennines. Systematic research on zooplankton communities started in the 1950s (Ferrari et al. 1992). Since then, several papers on calanoid copepods inhabiting this area have been published: Ferrari \& Ascolini (1975), Ascolini et al. (1979) and Rossetti et al. (1995, 2002) described the life cycle of E. intermedius in two oligotrophic lakes; the genetic variability and the reproductive biology of populations of $M$. kupelwieseri have been investigated by Rossi et al. (1995, 1998).

The present research aimed to analyse the factors (morphometric features, lithology, hydroperiod and hydrochemistry) affecting the distribution of calanoid species in lakes and ponds of the Northern Apennines, and to assess their persistence over time in response to natural and anthropogenic disturbance. Moreover, attention was paid to the main ecological traits of the calanoid populations, in particular to the reproductive patterns of $E$. intemedius in the different environmental conditions which characterise the limnic waters under study.

\section{METHODS}

In 1999, 89 water bodies were sampled. They are located in 8 valleys (Aveto, Trebbia, Nure, Arda, Taro, Parma, Cedra and Enza) on the northern slopes of 
Northern Apennines, at an altitude between 877 and $1772 \mathrm{~m}$ a.s.l.; the tree-line limit in the study area is about $1600 \mathrm{~m}$ a.s.l. The sampling sites (Appendix 1) vary from relatively large, deep, and thermally stratified lakes (e.g., Lago Santo Parmense, maximum depth 22.5 $\mathrm{m}$, surface area $8.2 \mathrm{ha}$ ) to very shallow, ephemeral pools which are highly unpredictable in relation to the filling period and its duration. Most of the sites have been visited seasonally during the ice-free period (from May to November). Information on analytical methods as well as the complete database containing detailed information on sampling sites and chemical analyses are available from the first author (S.T.).

For each biotope on each sampling date, water samples were collected from the surface layer and kept refrigerated until analysed. Two zooplankton samples were also gathered with a $50 \mu \mathrm{m}$ net: one was immediately preserved in a $4 \%$ buffered formaline solution, the other was kept alive to obtain animals for laboratory cultures. Identification of calanoid was done to species level using adult males dissected in glycerine and stored in sealed slides. The works by Dussart (1967) and Stella (1984) were used as reference texts. In samples containing Eudiaptomus intermedius, the population structure was analysed through the identification of the different stages (nauplii, copepodites and adults).

Principal Component Analysis for Categorical Data (CATPCA) was applied to analyse the distribution of calanoid species in relation to habitat characteristics (surface area, hydroperiod, altitude, maximum depth, basin lithology). Canonical Discriminant Function Analysis (CDA) was used to represent the distribution of two most common species, Mixodiaptomus kupelwieseri and E. intermedius, in relation to hydrochemical parameters. For CDA, selected variables were used after a $\log (\mathrm{x}+1)$ transformation: $\mathrm{pH}$, conductivity, total alkalinity, dissolved reactive phosphorus and dissolved inorganic nitrogen (calculated as sum of inorganic ammonia, nitrite and nitrate). The statistical analyses were performed by means of the package SPSS 11.0.1 for Windows.

From samples collected in 15 biotopes, living females of E. intermedius carrying egg sacs were sorted within 24 hours under a stereomicroscope and individually transferred into a $2.5 \mathrm{ml}$ well of multiwell plastic tissue culture plates containing mineral water. The animals were maintained at room temperature under natural light; the green alga Scenedesmus acutus was provided as food. Wells were checked weekly and eggs that did not hatch within 20 days were considered to be diapausing. Abortive eggs were easily distinguished from diapausing eggs: the former ones are transparent and are usually found in a limited number into a clutch, the latter ones have a bright red colour (de Stasio 1989; Rossi et al. 1998). Additionally, the dormant state of a subsample of eggs classified as diapausing was confirmed using the method proposed by Lohner et al. (1990).

\section{RESULTS}

Calanoid copepods were observed in 50 out of 89 sampled sites. Mixodiaptomus kupelwieseri was found in 24 water bodies, Eudiaptomus intermedius in 25 and $M$. tatricus only in two. In samples collected in a permanent pond of the Nure Valley (Moo, $1117 \mathrm{~m}$ a.s.l.), two calanoid species were found in different seasons, i.e. E. intermedius in July and M. kupelwieseri in October. During a previous limnological survey a similar successional pattern was observed in a temporary pond (Code d'Asino) of the Aveto Valley (Rossetti, unpublished); in 1999 no calanoids were found in this pond. In all other sites no more than one calanoid species was recorded.

An ephemeral pool (Gelata, Nure Valley) was completely dried out on the three surveys carried out in 1999; adults of $M$. kupelwieseri were found there in a sample collected in October 1998 (Rossetti, unpublished).

The results of CATPCA for the first two components are presented in the diagrams of figure 1 . The percentage of explained variance is 50.9 and 29.6 for the first and second axis, respectively. The ordination of species shows a clear overlap in the altitudinal distribution of $M$. kupelwieseri and E. intermedius. However, M. kupelwieseri preferentially colonises very shallow, temporary or ephemeral wetlands, especially those located on ophiolite outcrops. On the other hand, E. intermedius is generally found in permanent, relatively deep water bodies, although it can also inhabit temporary (Pozza NO Buono) or ephemeral pools (Pozza SO Buono, Pozza presso Monte Acuto) and ponds that occasionally dry out (Scuro di Rigoso). This species is more common in watersheds with a prevalence of sandstone rocks. The third calanoid species, M. tatricus, was found only beyond $1700 \mathrm{~m}$ a.s.l. in two shallow pools of the Cedra Valley (Pozza 8 and Lago Bicchiere). Shallower and scarcely predictable environments seem to be less suitable for calanoid settlement; in a lesser number of cases, diaptomids are also absent from large and deep lakes (e.g., Bino Maggiore, Gemio Inferiore, Verde and Calamone).

In figure 2 the CDA ordination of the two most common diaptomid species in relation to the chemical characteristics of the water bodies is showed. Correlations between the variables and the discriminant scores associated with the discriminant functions are reported in table 1 . On the first axis, which explains $86.3 \%$ of the total variance, $M$. kupelwieseri and E. intermedius form two clear, partially overlapping clusters which indicate a distribution pattern mostly related to the mineral content of waters. Mixodiaptomus kupelwieseri prefers well buffered waters with higher values of conductivity and total alkalinity. Conversely, Eudiaptomus intermedius can inhabit waters with weak ion concentrations, also having conductivity and alkalinity values below the acidification risk thresholds, respectively $20 \mu \mathrm{S} \mathrm{cm}^{-1}$ and $0.2 \mathrm{meq}^{-1}$ (Viaroli et al. 1994). 

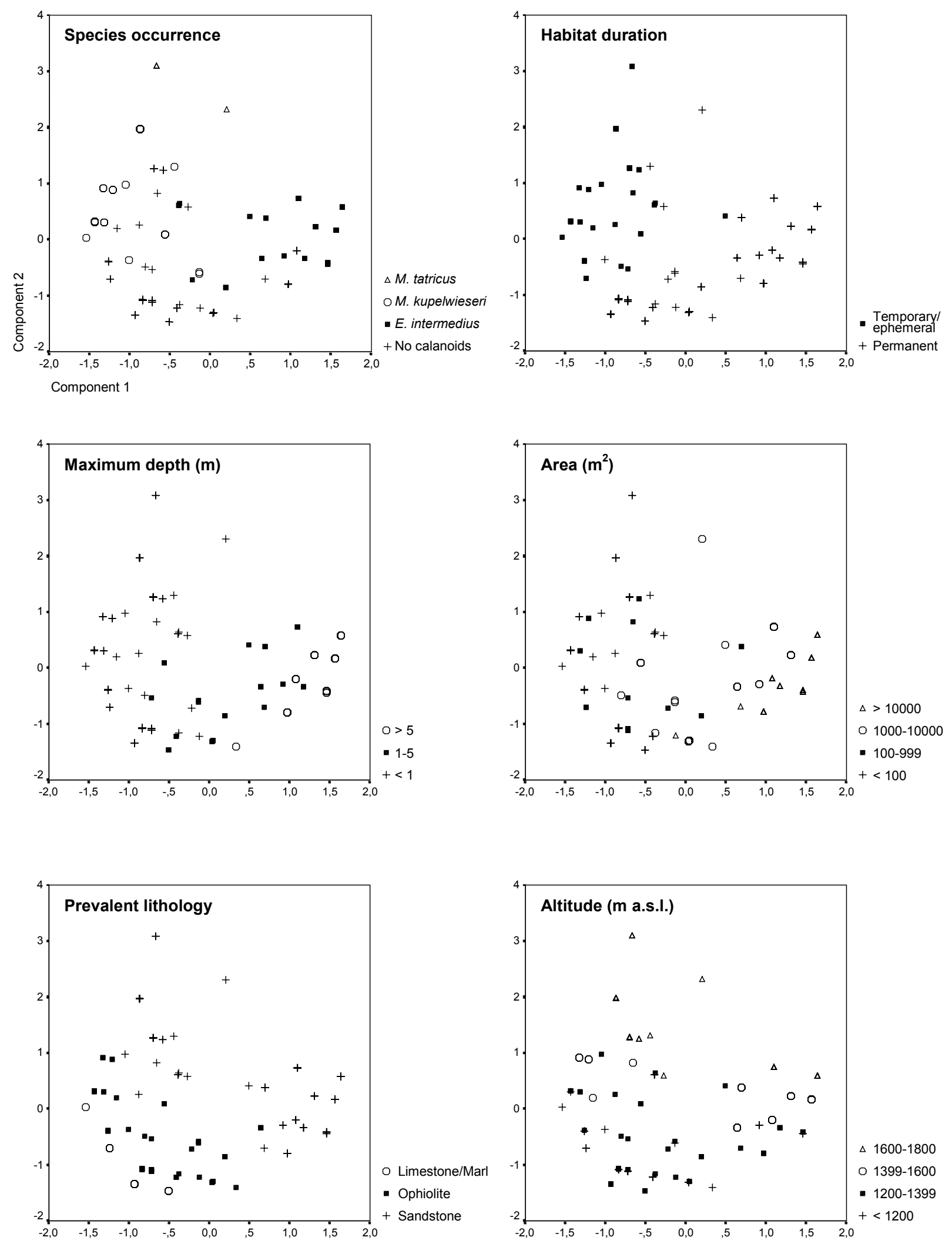

Fig. 1. Diagrams obtained from the Principal Component Analysis for Categorical Data showing the distribution of three calanoid species found in the study area in relation to habitat characteristics. 


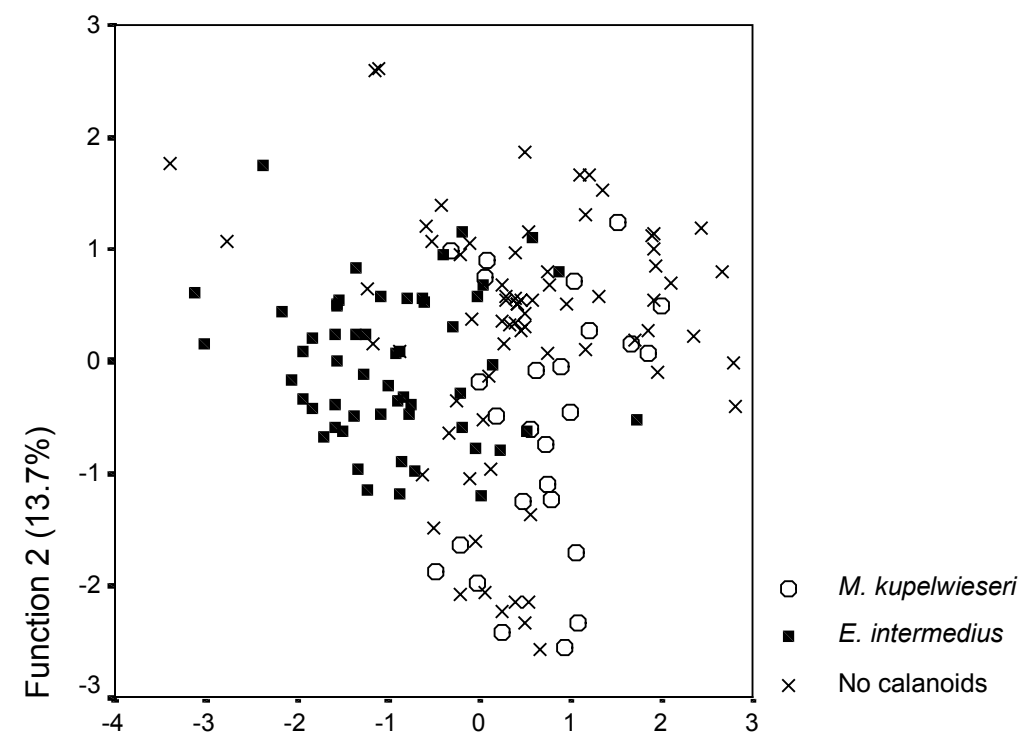

Function $1(86.3 \%)$

Fig. 2. Diagram obtained from the Canonical Discriminant Function Analysis representing the ordination of Mixodiaptomus kupelwieseri and Eudiaptomus intermedius in relation to chemical characteristics of the sampled biotopes.

Even though the concentrations of inorganic dissolved nutrients are less important in determining the observed ordination of the two species (Tab. 1), the results of the CDA indicate that M. kupelwieseri is preferentially found in more productive waters, while E. intermedius mostly colonises oligotrophic habitats. The absence of calanoids is weakly supported by the chemical characteristics of waters, although it is interesting to note that samples in which calanoids are lacking tend to aggregate towards the highest values of the first discriminant function.

Tab. 1. Structure matrix of the Canonical Discriminant Analysis.

\begin{tabular}{lcc}
\hline & \multicolumn{2}{c}{ Function } \\
\cline { 2 - 3 } & \multicolumn{1}{c}{1} & 2 \\
\hline $\mathrm{pH}$ & -0.103 & 0.887 \\
Conductivity & 0.574 & 0.813 \\
Total alkalinity & 0.580 & 0.741 \\
Dissolved inorganic nitrogen & 0.258 & 0.256 \\
Dissolved reactive phosphorus & 0.116 & 0.122 \\
\hline
\end{tabular}

Sampling frequency was not adequate to reconstruct the duration of the different development stages of $E$. intermedius. However, in most cases the analysis of the population structure allowed to determine the number of yearly generations. In deep water bodies adults overwinter under the ice cover and start to reproduce at the spring thaw. In permanent, oligotrophic habitats the reproductive period usually lasts until July, although in some years a second generation, sustained by scarce ovigerous females, may appear in autumn (as in the Santo Parmense and Scuro Parmense in 1999); this cohort most probably does not survive under the ice cover (Rossetti et al. 2002). In shallower or more productive permanent water bodies, more generations per year were observed (e.g., Buono and Palude del Verde). In the few temporary habitats in which $E$. intermedius occurs, the number of generations is less predictable and may change in different years, depending on the duration of the filling phase. In 1999 ovigerous females were found only in autumn in the following temporary or ephemeral water bodies: Pozza NO Buono, Scuro di Rigoso and Pozza presso Monte Acuto; in the Pozza SO Buono, ovigerous females were present in the samples collected both in July and October.

The percentages of clutches of E. intermedius with subitaneous eggs collected in different habitats are shown in table 2 . The eggs belonging to a brood turned out to be all resting or all subitaneous. Subitaneous eggs of a single clutch hatched almost simultaneously, within few days after the deposition. Due to the size of the samples, figures reported in table 2 should be considered with caution. Anyway, it is evident that $E$. intermedius may occasionally produce diapausing eggs also in permanent and relatively deep lakes, i.e. in more predictable environments like the Scuro Parmense. In other permanent habitats, less stable because smaller and shallower (Palude del Verde, Martini and Compione Inferiore), the percentage of resting eggs seems to be higher. As expected, in temporary and ephemeral habitats the production of resting eggs is overwhelmingly prevalent. 
Tab. 2. Analysis of egg clutches of E. intermedius collected in 1999 from different biotopes. P: permanent; T: temporary; E: ephemeral; N: number of egg sacs examined; \%: proportion of clutches with subitaneous eggs.

\begin{tabular}{lcccc}
\hline Biotope & Habitat & Sampling date & N & $\%$ \\
\hline Riondo & $\mathrm{P}$ & November, 03 & 3 & 100 \\
Bino Minore & $\mathrm{P}$ & July, 19 & 4 & 100 \\
Nero & $\mathrm{P}$ & November, 04 & 15 & 100 \\
Buono & $\mathrm{P}$ & July, 27 & 12 & 100 \\
Pozza SO Buono & $\mathrm{E}$ & October, 29 & 6 & 0 \\
Pozza NO Buono & $\mathrm{T}$ & October, 29 & 6 & 17 \\
Santo Parmense & $\mathrm{P}$ & October, 14 & 5 & 100 \\
Pradaccio & $\mathrm{P}$ & July, 27 & 18 & 100 \\
Scuro Parmense & $\mathrm{P}$ & July, 27 & 20 & 85 \\
& & October, 14 & 1 & 100 \\
Palude del Verde & $\mathrm{P}$ & June, 19 & 24 & 42 \\
& & July, 29 & 18 & 89 \\
& & October, 05 & 16 & 56 \\
Martini & $\mathrm{P}$ & June, 29 & 9 & 67 \\
Compione Inferiore & $\mathrm{P}$ & August, 03 & 12 & 75 \\
Sillara Superiore & $\mathrm{P}$ & June, 29 & 3 & 100 \\
Scuro di Rigoso & $\mathrm{T}$ & October, 16 & 6 & 0 \\
Paduli & $\mathrm{P}$ & September, 14 & 5 & 100 \\
\hline
\end{tabular}

\section{DISCUSSION}

The calanoid assemblage of the Northern Apennines shows interesting peculiarities. Eudiaptomus intermedius is an Eastern alpine - Illyric species and the study area is the western limit of its distribution (Stella 1979). Mixodiaptomus kupelwieseri has a broader distribution, being widespread in Central Europe and in circumediterranean areas (Dussart \& Defaye 2002), but it is rarely found at high elevations (Stella 1979). Both species do not occur in the Alps, contrary to M. tatricus (Giussani et al. 1986; Jersabek et al. 2001).

The results of this study clearly indicated that environmental constraints (morphometry, lithology, hydroperiod and hydrochemistry) are important in determining the species distribution. Mixodiaptomus tatricus is a stenotopic mountain species that is confined to high elevation pools which completely dry out or are seasonally subject to marked volume reductions. Mixodiaptomus kupelwieseri preferentially colonises temporary or ephemeral habitats, with waters well buffered and rich in inorganic nutrients. Eudiaptomus intermedius is mostly found in permanent, oligotrophic water bodies with a distinct pelagial zone and low solute concentrations. Records of E. intermedius prevail in watersheds in which sandstone is dominant, those of $M$. kupelwieseri in areas with maphic and ultramaphic rocks.

Only a case of two syntopic species has been recorded, but they show seasonal differences. For E. intermedius and M. kupelwieseri, species with a coinciding altitudinal distribution in the study area and comparable size (length of adult females: $1.3-2.0 \mathrm{~mm}$ in $E$. intermedius, $1.5-2.4 \mathrm{~mm}$ in $M$. kupelwieseri), co-occurrence may be prevented by competition for food particles of the same dimensional range. Indeed, there are contrasting evidences on the possible coexistence of calanoid species with similar size (see Maly \& Maly 1997 and references herein).

The observed distributional pattern may also depend on other adaptive factors that were not examined in the present study. For example, the colonisation of shallow and unpredictable habitats by M. kupelwieseri could be determined by its ability to modulate the duration of the life cycle in relation to the hydroperiod. For organisms that exploit temporary ponds, selection has favoured rapid colonisation, rapid growth rate and the ability to assay the triple risk of competition, predation and desiccation (Wilbur 1997). This species could also had developed strategies to minimize damage when exposed to solar ultraviolet radiation (Sommaruga 2001). On the other hand, E. intermedius can survive in scarcely productive habitats and successfully compete with other pelagic, efficient grazers as Daphnia longispina, a species to which is typically associated in oligotrophic lakes of the study area (Tavernini \& Rossetti 2001).

The production of diapausing eggs and their viability in different experimental conditions have been analysed by Rossi et al. (1998) in apenninic populations of $M$. kupelwieseri. Following Stella (1984), also M. tatricus produces resting eggs. The present study demonstrated for the first time that $E$. intermedius can lay diapausing eggs, occasionally also in predictable environments (see Santer 1998 and references herein for the adaptive significance of calanoid diapause in permanent lakes). However, available data do not allow any conclusions to be drawn about the comparative dispersion ability of the three species. In isolated ecosystems (as lakes and temporary ponds) also stochastic processes, for example the order of arrival of colonising species ("priority effects"), may play an important role in determining the structure of natural communities (Blaustein \& Margalit 1996; Wilbur 1997; Ward \& Thornton 2000).

Some biotopes in the study area resulted to be devoid of calanoids. For shallow pools, habitat conditions (e.g., sudden and intense variations of physical and chemical parameters or extreme unpredictability) may be too severe to allow the presence of calanoids. It is also probable that the persistence of these species is hampered by the lack of refugia against invertebrate (e.g. insect larvae) and vertebrate (e.g., amphibians) predation. In deeper basins as Calamone and Gemio Inferiore, disappearance of calanoids was associated with an evident decrease in water quality due to morphometric changes (construction of weirs) and tourist exploitation (presence of recreational resorts and massive trout introduction for angling); in these two lakes, calanoids were present in the early 1990s (Viaroli et al. 1994). However, the effect of fish on diaptomids is appreciable only if stocking load is well beyond the lake carrying capacity and eventually it can adversely alter the ecosystem functioning. In fact, the size of stocked trout is large enough to guarantee a negligible predation on the 
zooplankton community and the Northern Apennines lakes maintain only non-reproducing trout (Nonnis Marzano, pers. comm.). For example, Lago Santo Parmense has a long history of exploitation, since documented trout introductions have started at the beginning of the last century (Brian 1924). In spite of this, the population of E. intermedius still persists with high densities (Rossetti, unpublished).

Some differences emerge when the calanoid distribution determined in this study is compared with data collected in the 1950s and 1960s (Moroni 1962, 1966; Gandolfi 1965; Andrei \& Gandolfi 1965; Bonazzi \& Ferrari 1966). The frequent occurrence in recent samples of $M$. kupelwieseri, first reported in the study area by Manzoni et al. (1992), depends to a large extent on a greater sampling effort in temporary and ephemeral environments; additionally, previous identification of this species might have been wrong (Rossetti et al., submitted). Apart from the above mentioned cases of manifest deterioration of the trophic conditions for some lakes, calanoid populations appear to have persisted in permanent and deep habitats over the decades elapsed since the first faunistic surveys carried out in the Northern Apennines. Reliable data from previous investigations on the zooplankton of temporary pools are less numerous. However, when comparison is possible, also for these habitats exposed to a high degree of natural disturbance the persistence of the calanoid species can be evidenced. The most interesting example is the temporary pond Asperelle, where the presence of Diaptomus apenninicus (later on synonymised with M. kupelwieseri) was first reported in samples collected in 1923 (Brian 1927).

\section{CONCLUSION}

Calanoid copepods act as influential species in freshwater ecosystems. The study of their dispersal mechanisms, colonisation patterns and life histories is essential to understand the mechanisms affecting the structure and evolution of zooplankton communities. This research dealt with the distribution of calanoid species in relation to physiographic and chemical characteristics of lakes and ponds of the Northern Apennines. The main ecological traits and reproductive modes of calanoid populations have been analysed. Attention has also been paid to small and ephemeral water bodies present in this area, which have scarcely taken into account in previous investigations. For most of the lentic environments under study, availability of long term data sets allowed to assess the persistence of calanoid species over the last decades.

The marginal ecosystems considered in this research are particularly fragile, due their susceptibility to anthropogenic impacts, both at local (e.g. stocked trout) and global scale (e.g. atmospheric warming and depletion of the ozone layer). Monitoring programs and mitigation plans are needed to ensure an acceptable level of environmental quality. In this regard, calanoids appear to be particularly sensitive to habitat alteration and their decline or disappearance can be interpreted as an early symptom of ecosystem stress.

\section{ACKNOWLEDGMENTS}

We acknowledge the Dipartimento Politiche di Gestione del Territorio e Tutela dell'Ambiente dell'Amministrazione Provinciale di Piacenza, the Coordinamento Regionale per la Liguria del Corpo Forestale dello Stato, and the Parco Regionale dei Cento Laghi for their profitable help. We are grateful to Prof. Ireneo Ferrari for reading an earlier draft of the manuscript and for his useful comments.

\section{REFERENCES}

Andrei, M. \& G. Gandolfi. 1965. I laghi di Val Nure. Boll. Pesca Pisc. Idrobiol., 20: 61-142.

Ascolini, A., G. Di Cola \& I. Ferrari. 1979. Production of Eudiaptomus intermedius in Lake Santo Parmense. Boll. Zool., 46: 145-151.

Blaustein, L. \& J. Margalit. 1996. Priority effects in temporary pools: nature and outcome of mosquito larva-toad tadpole interactions depend on order of entrance. J. Anim. Ecol., 65: 77-84

Bonazzi, G. \& I. Ferrari. 1966. Il sistema lacustre di Val d'Enza. Boll. Pesca Pisc. Idrobiol., 21: 57-144.

Brian, A. 1924. Il Lago Santo Parmense sotto l'aspetto faunistico. Biblioteca della Giovane Montagna, 27: 3-11.

Brian, A. 1927. Copepodi raccolti in alcuni laghi delle Alpi e dell'Appennino e descrizione di nuove forme di Diaptomus. Mem. Soc. Entom. Ital., 6: 26-36.

Brian, A. 1932. Intorno alla distribuzione geografica di alcuni Diaptomus (Crostacei Copepodi) nei laghetti dell'Appennino Settentrionale. Riv. Geogr. Ital., 9/10: 121-128.

de Stasio, B.T. Jr. 1989. The seed bank of a freshwater crustacean: copepodology for the plant ecologist. Ecology, 70: 1377-1389.

Dussart, B. 1967. Les Copépodes des eaux continentales d'Europe occidentale. I. Calanoïdes et Harpacticoïdes. Boubée et Cie, Paris: 500 pp.

Dussart, B. \& D. Defaye. 2002. World directory of Crustacea Copepoda of inland waters. I. Calaniformes. Backhuys Publ., Leiden: 276 pp.

Ferrari, I. \& A. Ascolini. 1975. Life cycle of Eudiaptomus intermedius (Steuer) (Copepoda, Calanoida) in a mountain lake. Boll. Zool., 42: 39-47.

Ferrari, I., P. Menozzi \& A. Moroni. 1992. Research on northern Apennine lakes and aquatic systems in the Po Plain, Italy. Mem. Ist. ital. Idrobiol., 50: 273-294.

Gandolfi, G. 1965. Gli ecosistemi lacustri di Val Trebbia (Appennino Ligure-Emiliano). Aspetti di fisiografia ed ecologia dei popolamenti zooplanctonici. Graduation thesis, University of Parma.

Giussani, G., R. de Bernardi, R. Mosello, I. Origgi \& T. Ruffoni. 1986. Indagine limnologica su i laghi alpini d'alta quota. Documenta Ist. ital. Idrobiol.: $415 \mathrm{pp}$.

Jamieson, C.D. 1998. Calanoid copepod biogeography in New Zealand. Hydrobiologia, 367: 189-197.

Jersabek, C.D., A. Brancelj, F. Stoch \& R. Schabetsberger. 2001. Distribution and ecology of copepods in mountainous regions of the Eastern Alps. Hydrobiologia, 453/454: 309-324.

Liss, W.J., G.L. Larson, E.A. Deimling, L.M. Ganio, R.L. Hoffman \& G.A. Lomnicky. 1998. Factors influencing the distribution and abundance of diaptomid copepods in 
high-elevation lakes in the Pacific Northwest, USA. Hydrobiologia, 379: 63-75.

Lohner, L., N.G. Jr. Hairstone \& W. Schaffner. 1990. A method for distinguish subitaneous and diapausing eggs in preserved samples of the calanoid copepod genus Diaptomus. Limnol. Oceanogr., 35: 763-767

Maly, E.J. \& M.P. Maly. 1997. Predation, competition, and co-occurrences of Boeckella and Calamoecia (Copepoda: Calanoida) in western Australia. Hydrobiologia, 354: 4150 .

Manzoni, C., G. Rossetti, P. Viaroli, I. Ferrari \& L.Cagnolaro. 1992. Idrochimica e popolamenti zooplanctonici dei laghi e delle pozze del Monte Aiona (Appennino Ligure). Atti IX Congresso AIOL: 119-129.

Moroni, A. 1962. I laghi della Val Parma. L'Ateneo Parmense. Monografia 8, Parma: $129 \mathrm{pp}$.

Moroni, A. 1966. I laghi di Val Cedra. Boll. Pesca Pisc. Idrobiol., 21: 163-266.

Rossetti, G., E. Fratta, F. Tireni \& S. Viglioli. 2002. Impact of a fungal parasite on the reproductive potential of the freshwater calanoid Eudiaptomus intermedius. Verh. int. Ver. Limnol., 28: 387-391.

Rossetti, G., S. Sei, G. Paris \& I. Ferrari. 1995. Ciclo biologico di Eudiaptomus intermedius (Copepoda, Calanoida) in un lago appenninico d'alta quota (Lago Scuro Parmense). S.It.E. Atti, 16: 471-473.

Rossi, V., G. Paris, G. Rossetti, S. Sei \& P. Viaroli. 1995. Analisi di popolazioni del copepode calanoide Mixodiaptomus kupelwieseri in corpi d'acqua dell'Appennino Ligure. Atti X Congresso A.I.O.L., : 117-124.

Rossi, V., L. Montesanto \& P. Menozzi. 1998. Deposition season and hatching patterns of resting eggs in Mixodiaptomus kupelwieseri (Crustacea: Copepoda). Arch. Hydrobiol. Spec. Issues Advanc. Limnol., 52: 207-218.

Santer, B. 1998. Life cycle strategies of free-living copepods in fresh waters. J. Mar. Syst., 15: 327-336.
Sommaruga, R. 2001. The role of solar UV radiation in the ecology of alpine lakes. J. Photochem. Photobiol. B: Biol., 62: $35-42$.

Stella, E. 1979. Considerazioni biogeografiche sui Diaptomidi (Copepoda Calanoida) delle acque dolci italiane. Lavori della Società Italiana di Biogeografia, 6: 315-328.

Stella, E. 1984. Fauna d'Italia. Crustacea. Copepoda: Calanoida (d'acqua dolce). Ed. Calderini, Bologna: $101 \mathrm{pp.}$

Tavernini, S. \& G. Rossetti. 2001. Lo zooplancton di laghi e pozze dell'appennino Ligure-Emiliano (Val d'Aveto, Val Trebbia, Val Nure, Val d'Arda e Val Taro). Studi Trent. Sci. Nat., Acta Biologica, 78: 139-148.

Torke, B. 2001. The distribution of calanoid copepods in the plankton of Wisconsin Lakes. Hydrobiologia, 453/454: 351-365.

Viaroli, P., I. Ferrari, A. Mangia, V. Rossi \& P. Menozzi. 1992. Sensitivity to acidification of Northern Apennines lakes (Italy) in relation to watershed characteristics and wet deposition. In: R. Mosello, B.M. Wathne \& G. Giussani (Eds), Limnology on groups of remote lakes: ongoing and planned activities. Documenta Ist. ital. Idrobiol., 32: 93-105.

Viaroli, P., I. Ferrari, G. Paris, G. Rossetti \& P. Menozzi. 1994. Limnological research on Northern Apennine lakes (Italy) in relation to eutrophication and acidification risk. Hydrobiologia, 274: 155-162.

Walsh, R.G.J. \& P.A. Tyler. 1998. Reconnaissance limnology of Tasmania IV. The distribution and ecological preferences of Tasmanian species of freshwater calanoid copepods (Crustacea: Centropagidae). Arch. Hydrobiol., 141: 403-420.

Ward, S.A. \& W.B. Thornton. 2000. Chance and determinism in the development of isolated communities. Global Ecol. \& Biog., 9: 7-18.

Wilbur, H.M. 1997. Experimental ecology of food webs: complex systems in temporary ponds. Ecology, 78: 22792302 .

Received: December 2002

Accepted: January 2003

Appendix 1. List of the water bodies considered in this study. Hydroperiod $(\mathrm{P}=$ permanent; $\mathrm{T}=$ temporary; $\mathrm{E}=$ ephemeral) and altitude ( $m$ a.s.l.) are reported for each site (in brackets).

Aveto Valley: Lagastro (T, 1330); Lago degli Abeti (P, 1328); Riondo (P, 1328); Lago di Fondo (P, 1326); Lago di Mezzo (P, 1327); Code d'Asino (T, 1275); Scuro delle Agoraie (T, 1285); Lago delle Lame (P, 1043); Asperelle (T, 1267); Piccolo (Superiore Agoraie) (T, 1331).

Trebbia Valley: Averaldi (T, 1095); Santa Barbara (T, 1136); Elisa (E, 1114); Sella dei Generali (T, 1221); Curiasca Peli 1 (P, 1339); Curiasca Peli 2 (P, 1338); Curiasca Peli 3 (P, 1370).

Nure Valley: Bino Maggiore (P, 1295); Bino Minore (P, 1296); Roccone 1 (T, 1210); Roccone 2 Maggiore (P, 1230); Roccone 2 Minore (E, 1230); Moo (P, 1117); Faggio (E, 1117); Boccalona (P, 990); Gelata (E, 1190); Lagazzo (P, 911); Nero (P, 1540); Buche di Monte Nero (T, 1479); Moggia Rossa (T, 1434); Poggio del Laghetto (T, 1383); Nisora Superiore (P, 1335); Nisora Mediano (T, 1330); Nisora Inferiore (T, 1320); Marani Superiore (P, 1390); Marani Inferiore (P, 1390).

Arda Valley: Lago del Gallo (P, 877); Lago del Rudo (P, 905); Pozza 1 Pellizzone (T, 1096); Pozza 2 Pellizzone (T, 1096).

Taro Valley: Buono (P, 1140); Pozza SO Buono (E, 1156); Pozza NO Buono (T, 1135).

Parma Valley: Santo Parmense (P, 1507); Padre (P, 1528); Pradaccio (P, 1430); Bicchiere (P, 1724); Scuro Parmense (P, 1527); Gemio Superiore (P, 1355); Gemio Inferiore (P, 1339); Pozza presso Gemio Inferiore ( $T$, 1339); Pozza 1 Navert (T, 1650); Pozza 2 Navert (T, 1650); Monte Caio (E, 1430).

Cedra Valley: Ballano (P, 1341); Verde (P, 1507); Palude del Verde (P, 1508); Frasconi (P, 1606); Pozza presso Frasconi (T, 1606); Sillara Superiore (P, 1732); Sillara Inferiore (P, 1731); Martini (P, 1714); Compione Superiore (P, 1686); Compione Inferiore (P, 1674); Pozza 1 (T, 1675); Pozza 2 (T, 1718); Pozza 3 (T, 1681); Pozza 4 (T, 1686); Pozza 5 (T, 1676); Pozza 6 (T, 1692); Pozza 7 (T, 1691); Pozza 8 (T, 1705); Pozza 9 (T, 1712); Pozza 10 (T, 1712); Pozza 11 (T, 1728); Pozza 12 (T, 1772); Torbiera Rocca Pianaccia (T, 1712); Paitino 1 (T, 1716); Lago Rocca Pianaccia (P, 1656); Paitino 3 (T, 1680); Palo (P, 1508); Verdarolo (P, 1390); Scuro di Rigoso (T, 1392).

Enza Valley: Calamone (P, 1396); Le Cambre (T, 1335); Lago di Monte Acuto (P, 1576); Pozza presso Monte Acuto (T, 1251); Paduli (P, 1160); Squincio (P, 1241). 